\title{
Reception of biblical discourse in Africa
}

Author:
Itumeleng D. Mothoagae ${ }^{1}$
Affiliation:
'Department of Biblical and
Ancient Studies, School of
Humanities, University of
South Africa, Pretoria,
South Africa
Corresponding author:
Itumeleng D. Mothoagae,
mothodi@unisa.ac.za
How to cite this article:
Mothoagae, I.D., 2021,
'Reception of biblical discourse
in Africa', HTS Teologiese
Studies/Theological Studies
77(1), a7204. https://doi.
org/10.4102/hts.v77i1.7204
mobile device
to read online.
Copyright:
Read online:
2021. The Authors.
Licensee: AOSIS. This work
is licensed under the
Creative Commons
Attribution License.

The articles published in this issue of HTS Teologiese Studies/Theological Studies were subjected to a rigorous blind peer review process in accordance with the required academic standard set for this journal. Authors in this special collection engage on the topic of the reception of biblical discourse in Africa from various perspectives. African biblical scholars, particularly those taking their points of departure from postcolonial, translational and decolonial theories, as well as scholars within social sciences have argued that the Christian corpus of literature that was produced during 'evangelisation' of the 'heathen' is a colonial product. As such, in analysing such literature it is imperative that such an analysis locates these body of literature within the broader imperial, colonial and epistemic discourse as indispensable channels of imperial conquest and occupation of the time.

Creating a variety of material, commenting on the Bible as primary text was an effective mechanism that allowed the imperial conquerors to communicate with their 'subjects'; it was also a way of developing new mechanisms of subjecting them and converting them into docile cooperative subjects. Recognising these texts and hymns as discursive acts at work in Christian communities as commentary on a primary narrative imported from Europe and contextualised in Africa, requires enquiry into the colonialist agenda of which these are products, not only in order to subvert and expose, and to decolonise, but also to move beyond their decolonisation.

The papers in this special collection apply various theoretical lenses in their analysis of biblical discourse in South Africa. Kok, applying a decolonial reading of the parables in the New Testament, argues that the New Testament can be read critically through the lens of core ideas of Fanon and Biko in critical correlation with understandings of Jesus as reacting against Roman Imperial domination and exploitation. He concludes that following Jesus' example, disenfranchised, displaced and dislocated people can also be empowered to continue the struggle against colonial domination, oppression and exploitation. Particularly in a world of haves and have-nots, which was also the reality in Jesus' time, we clearly see Jesus standing on the side of the have-nots. Jesus was a true revolutionary, and those who have a heart for black consciousness will find in this decolonised Jesus someone who stood up for the poor and marginalised, and showed that God is especially present with the downtrodden.

Buffel, in his paper, engages with the notion of poverty, COVID-19 and vaccine nationalism. He applies Black Theology as his analytical lens. According to him, COVID-19 has exacerbated the levels of poverty, inequality and increased unemployment. While the disenfranchised may be experiencing these harsh conditions, in their spiritual journeys they encounter God and each other at a hermeneutical nexus and at a point where their biblical theology meets Black Theology.

Senokoane analyses the intersectionality of biblical and public discourses. He argues that such a discourse borders on biblical fundamentalism. This according to him needs to be taken seriously, particularly when a biblical text is used to engage science. He draws the attention of the use of the notion of 666 in the 'Book of Revelation' in conjunction with the COVID-19 vaccine. He cautions against reading a text out of its socio-historical conditions. He concludes that a critical reading of the text leads to appreciation of the socio-historical of the text and provides various perspectives to the text, something that appears to be lacking in those churches that make claims that vaccine contains foetal tissues or microchips, as well as construing and associating ingredients of vaccines with the devil. While others associate Coronavirus vaccines and masks as containing the 'mark of the beast'.

Netshapapame and Mavhandu-Mudzusi engage with the notion of biblical discourse within the context of HIV and AIDS. They argue that the response of the church across denominations to the HIV or AIDS pandemic has varied. There were those denominations that chose to be silent, while others engaged in a biblical discourse of public and private condemnation of the disease.

Note: Special Collection: Reception of Biblical Discourse in Africa, sub-edited by Itumeleng Mothoagae (University of South Africa). 
While they concede that the church has made great endeavours to engage in a biblical discourse that seeks to encourage people to protect themselves from infection and those infected to live healthy and fruitful lives. They argue that a lot still needs to be done to enable those living with the virus to be agents of change. They further maintain that for the church to achieve this, through its leaders (pastors), it must engage in a new form of biblical discourse. In other words, using the biblical text as a tool for liberation, not enslavement. Such an approach will impact how the church ought to respond to HIV or AIDS and the gender question. This includes how religion as a technology of power can also be a vehicle of change in addressing the latest pandemic of COVID-19, at the same time not neglecting those infected and affected by HIV or AIDS.

Mothoagae's article locates biblical discourse in the 19th century missionary activities amongst the Batswana. He argues that the missionaries engaged in biblical discourse through public preaching, and a dialectical approach when engaging with members of the community. He further argues that part of their biblical discourse was to question the religio-cultural practices of their audiences. Mothoagae in his article analyses the public discourse about male and female initiations that took place in the public spaces and found their way into a newspaper named Mahoko a Becwana. He maintains that it is in these letters that the writers were engaging in biblical discourse, and according to him was between the missionaries, the converted and the traditional Batswana. Mothoagae analyses the notion of circumcision in the 1840 English-Setswana Gospel of Luke juxtaposing with the Setswana rite of initiation bogwera and argues that the symbol thupiso (circumcision) in the Gospel is transmuted into bogwera. He argues further that in his translation, Moffat engages in biblical discourse thus distorting the cultural meaning.
Masenya locates the notion of biblical discourse within the digital space. She engages the intersectionality of orality, gender and sacred texts in the digital era. She argues that there is an intersection between power, gender, orality and public discourse in general, and biblical discourse. According to Masenya the intersection of power, gender, orality and public (biblical) discourse, is also notable even in today's digital era. Female subordination, it may be argued, is not enhanced by the level of the technological advancement in a specific context. On the contrary, it may be argued that the digital space has come to expose not only the existing economic disparities between persons and countries, but also between genders even in the context of the delivery and/or people's engagement with biblical discourse in the context of tele-evangelism.

Lastly, Mdingi argues that the introduction of the Bible into Africa operated on two major frontiers, firstly, the oral tradition of the missionary who possessed both the Gospel message by word and in the written text (gadget). Conversion occurred through oral 'manipulation' then an oral negation of the native's history and worldviews. Secondly, the rise of missionary schools opened the door to the reading of the text. Mdingi concludes that technology and digitisation of the Bible at least through the liberationist paradigm cannot and should not deter the existential quest for justice and liberation as irrevocable conditions of the scripture. Technology is not paradise but ambience of possible fortune or peril, and black people must remain on guard.

These articles engage with the notion of biblical discourse from various perspectives, as such it draws attention to the need for theological and biblical sciences to decolonise in order to critically engage with the social and epistemic location of the Global South. 